\title{
Regulatory Competition and the Efficiency of Alternative Derivative Product Margining Systems
}

\author{
Paul H. Kupiec and A. Patricia White ${ }^{1}$
}

June 11, 1996

\footnotetext{
${ }^{1}$ Senior Economist and Assistant Director, Division of Research and Statistics, Board of Governors of the Federal Reserve System. The conclusions herein are those of the authors and do not represent the views of the Federal Reserve Board or any of the Federal Reserve Banks.
} 


\begin{abstract}
Although margin requirements would arise naturally in the context of unregulated trading of clearinghouse-guaranteed derivative contracts, the margin requirements on U.S. exchange-traded derivative products are subject to government regulatory oversight. At present, two alternative methodologies are used for margining exchangetraded derivative contracts. Customer positions in securities and securities options are margined using a strategy-based approach. Futures, futures-options, and securitiesoption clearinghouse margins are set using a portfolio margining system. This study evaluates the relative efficiency of these alternative margining techniques using data on S\&P500 futures-option contracts traded on the Chicago Mercantile Exchange. The results indicate that the portfolio margining approach is a much more efficient system for collateralizing the one-day risk exposures of equity derivative portfolios. Given the overwhelming efficiency advantage of the portfolio approach, the simultaneous existence of these alternative margining methods is somewhat puzzling. It is argued that the co-existence of these systems can in part be explained in the context of Kane's (1984) model of regulatory competition. The efficiency comparison also provides insight into other industry and regulatory issues including the design of bilateral collateralization agreements and the efficiency of alternative schemes that have been proposed for setting regulatory capital requirements for market risk in banks and other financial institutions.
\end{abstract}




\section{Regulatory Competition and the Efficiency of}

\section{Alternative Derivative Product Margining Systems}

\section{Introduction}

One of the key safeguards in the risk management systems of futures and options clearing organizations is the requirement that market participants post collateral, known as margin, to guarantee their performance on contract obligations. The need for risk management arises in exchange-traded futures and options markets because the clearing organization becomes the counterparty to all trades, guaranteeing the performance of trades between clearing members. ${ }^{1}$ In addition to the protection that margin offers clearing organizations from exposures to their clearing members, collateral requirements also are used to mitigate the risk that clearing members and broker-dealers are exposed to relative to their customers.

Although margin requirements would arise naturally in an unregulated exchangetraded derivative contract market, margining policies are subject to regulatory oversight. With respect to exchange-traded equity derivative products, three federal regulators have some role in determining margining systems. The margin levels and the margining systems used to set collateral requirements for stocks and stock options portfolios are subject to oversight from both the Federal Reserve Board (FRB) and the Securities and Exchange Commission (SEC). Although the levels of futures margins other than those on stock index futures contracts are not set by the Commodity Futures Trading Commission (CFTC), futures clearinghouse margining systems are subject to CFTC regulatory oversight. ${ }^{2}$ Thus regulations governing margining sys-

\footnotetext{
${ }^{1}$ Margin is one of an array of safeguards employed by clearing organizations that include membership and capital standards, frequent marking of positions to market, and liquidity facilities. See Edwards (1983) or Figlewski (1984) for further discussion.

${ }^{2}$ The CFTC has regulatory authority to approve futures clearinghouse margining systems (17CFR Section 1.41). Although the CFTC has the authority to approve the margining systems, for contracts other than stock index futures, sections 5(a)(12) and 8(a)(7) of the Commodity Exchange Act
} 
tems are either set directly by a government regulator or designed by a self-regulatory organization (SRO) and approved by the regulator with oversight authority. This system of government oversight has lead to margin regulations that have varied widely both over time and across markets.

This study evaluates the efficiency of the alternative systems that have developed to margin exchange-traded options and options on futures. Given its prudential function, a measure of the efficiency of a margining system is the amount of collateral it requires to provide a given degree of protection on a position or combination of positions. In an efficient system, margin collateral is minimized subject to the constraint of achieving the desired level of protection. Telser (1981), Figlewski (1984), and Fenn and Kupiec (1993) provide more detailed discussions of the design of an efficient margining system.

Two existing schemes for margining option instruments are contrasted. Regulation $\mathrm{T}$ (Reg $\mathrm{T}$ ), a strategy-based margining system used to set margin for customers holding equities and equity options in a margin account is compared with the Standard Portfolio Analysis of Risk (SPAN) margining system, a portfolio system used for margining clearing member and customer accounts for futures and futures-option products. The empirical analysis presented will document that the portfolio margining system adopted by futures exchanges (SPAN) is substantially more efficient than the strategy based margin approach (Reg T) that applies to customer positions in securities option markets. Over the sample period examined, SPAN provides virtually the same coverage of the one-day market risk of option portfolios as is provided by the strategy-based system of Reg T. SPAN, however, accomplishes this task with substantially smaller collateral requirements.

As empirical results indicate that existing option margining system differ widely

(CEA) expressly preclude the CFTC from exercising authority over the level of margins for futures transactions. Section 8(a)(9) of the CEA does give the CFTC authority under its emergency powers clause to set temporary margin levels in order to maintain or restore orderly trading in the futures markets. 
in their efficiencies, it is natural to question how the alternative systems evolved and why the alternative margining systems continue to co-exist. The regulatory competition model of Kane (1984) provides a framework that may in part explain the structure of these existing margin regulations. In Kane's model, competition among SROs, both with each other and with regulatory bodies charged with overseeing their operations, reduces the "regulatory tax" burden relative to direct governmental regulation. The evidence presented in this study is consistent with Kane's hypothesis that active regulatory competition among SROs will reduce the implicit "tax" associated with regulatory oversight. Specifically, the margin systems used for clearing member and market maker positions in both securities options markets and futures markets share the efficiency gains generated by adopting portfolio margining approaches. In areas lacking strong competition in the regulatory structure, such as the regulation of customer margins for options on securities, "regulatory tax" burdens appear to be unnecessarily high if margins are set to satisfy prudential purposes alone.

While the primary focus of this analysis is the relative efficiency of these alternative types of margining systems, this particular comparison also provides insight into other industry and regulatory issues including the design of bilateral collateralization agreements and the efficiency of alternative schemes that have been proposed for setting regulatory capital requirements for market risk in banks and other financial institutions.

\section{Issues Related to Margin Efficiency}

A measure of the efficiency of a margining systems is the amount of collateral it requires to provide a given degree of protection on a position or combination of positions. In an efficient system, margin collateral is minimized subject to the constraint of achieving the desired level of protection. The efficiency of alternative margining systems is primarily of interest because it affects the cost of carrying positions for 
market participants, and thus may affect the relative attractiveness of assuming a particular type of risk in a particular instrument or market. In many applications, futures and futures options are close substitutes for securities and securities options, and so the efficiency of a margining system may have competitive implications.

Other things equal, higher margin requirements provide greater assurance that collateral will not be exceeded. However, if margin requirements impose significant costs, the greater protection may come at the cost of less participation in markets. Although Anderson (1981) argues that margin requirements impose little cost because they can be satisfied by posting T-Bills or securities, the results of Fishe and Goldberg (1986), Tomek (1985), and Hartzmark (1986) show that changes in initial margin requirements in the futures markets have little or no effect on trading volume and a small but measurable effect on contract open interest - higher margins are associated with smaller open interest. Because positions opened and closed intra-day are not subject to clearinghouse margin requirements, these empirical results are consistent with the hypothesis that collateral requirements impose costs on market participants. Any reduction in market participation that owes to unnecessarily high margin requirements will reduce the economic benefits of risk-sharing and may adversely effect market liquidity.

While the primary focus of this analysis is the relative efficiency of these types of margining systems, this particular comparison provides insight into other industry and regulatory issues. For example, as over-the-counter (OTC) derivative markets continue to develop, collateralization is becoming a more common method for addressing the risks associated with counterparties of lesser quality [Petzel,(1995)]. Bilateral collateral agreements can be struck on an instrument by instrument basis, or alternatively, they can be based on a counterparty's portfolio exposure when enforceable netting agreements prevail. In these circumstances, the problems of setting the required amount of collateral and of valuing collateral in OTC related transactions are in many ways analogous to the margining problems faced by clearinghouses. 
In addition to private collateralization agreements, the results of this study have implications for the development of regulatory capital requirements for the market risk exposure of financial institution. Conceptually, determining margin requirements to protect against price changes and determining regulatory capital requirements for market risk are similar tasks. Banking supervisors currently are deciding methods for incorporating measures of market risk into the capital framework for banks. Alternative methods for handling market risk have been proposed that embody features of strategy and portfolio margining techniques. For example, the April 1993 Basle approach for market risk capital requirements specifies bonds of particular maturity that can serve as hedges for each other. This so-called "standardized approach" for setting market risk capital requirements is a strategy-based approach. Alternatively, the so-called "internal models approach" outlined in the 1995 Basle Supervisors proposal allows institutions to use their internal risk management models to determine market risk. ${ }^{3}$ This latter approach is similar to portfolio margining. Thus, although the empirical results of this study are specific to the margining systems examined, the comparison is relevant to the debate surrounding the setting of market risk capital requirements for banks.

\section{A Comparison of SPAN and Reg T Margining Systems}

Strategy-based margin systems are a set of rules that define the collateral requirements for specific combinations of positions. For example, a strategy-based margin system might specify precise put, call, and underlying positions that can serve as offsets for each other and thereby reduce collateral requirements. Under such a system, combinations of positions not specifically identified in the requirements are treated as if they were held in isolation. A strategy-based system currently is used in securities markets for margining customer positions involving equity options and underlying

\footnotetext{
${ }^{3}$ For a discussion of these bank capital approaches, see Kupiec and O'Brien (1996).
} 
stocks.

Portfolio margining systems evaluate positions as a group and determine collateral requirements based upon estimates of changes in the value of the portfolio that would occur under assumed changes in market conditions. Margin requirements are set to cover the largest portfolio loss generated by a simulation exercise that includes a range of potential market conditions. Because the technique considers the total value of the portfolio in different scenarios, portfolio margining allows positions implicitly to offset each other without specifically designating one position as the offset for another. Portfolio margining is currently applied at both the clearing member and the customer level in futures markets. It is also the margin technique used for clearing member and market maker margins at the Options Clearing Corporation (OCC), the clearinghouse and guarantor of U.S. exchange-traded securities options.

In the following sub-sections, the SPAN portfolio margining system used by futures clearinghouses and the strategy-based rules from Reg $\mathrm{T}$ are described. These two systems are then evaluated by comparing the collateral requirements for several different types of positions with the actual value-changes recorded by these positions as of market close on the subsequent day. The analysis is conducted using price data on futures-options on the Standard and Poor's 500 stock index (S\&P500) traded on the Chicago Mercantile Exchange (CME).

\section{The SPAN Portfolio Margining System}

SPAN margins are derived from estimates of changes in futures and futures-option contract prices that would occur under scenarios that assume changes in underlying market conditions. This portfolio margining system estimates the riskiness of a portfolio of related contracts from the maximum possible loss that is generated from a simulation analysis. The time dimension for margin setting is one day in futures and options markets. In the simulations, the scenarios estimate losses that might be generated by potential one-day changes in underlying prices or implied volatility. 
Thus, the margin collateral is designed to protect the clearing process over the next day.

SPAN uses the Black (1976) model to simulate one-day potential changes in the value of futures contracts. ${ }^{4}$ Under SPAN, futures and futures-options price changes are estimated under alternative scenarios that are determined by the values chosen for the price and implied volatility scan range inputs. Kupiec (1994) provides a more detailed description of the SPAN margining system.

A clearinghouse sets the input values for the SPAN simulations that ultimately determine the portfolio's margin requirement. The price scan range setting in SPAN determines the maximum underlying price move that the clearinghouse margin committee chooses to consider in setting collateral requirements. For futures, the price scan range is the maintenance margin requirement on a naked futures position. The implied volatility scan range input into SPAN is the largest movement in implied volatility that the margin committee chooses to protect against. These scan ranges are set by the clearinghouse after examining historical price movements and applying subjective judgments. Historical values of all SPAN input settings for the S\&P500 stock index futures contract traded on the CME are detailed in table 1.

Other control parameters of the SPAN system potentially play an important role in the ultimate determination of the degree of protection afforded by the system. These additional features include the treatment of short option positions and the margin treatment of spread positions. Short option minimum margin and spread adjustment parameters are not an integral part of a portfolio system but rather are corrections for situations in which the clearinghouse has determined that the basic portfolio system does not adequately margin for risk.

The value of options that are significantly out-of-the-money change little when the price of the underlying contract varies unless that latter price move is large enough

\footnotetext{
${ }^{4}$ The option pricing model used in the portfolio margining system of the OCC's clearing members (TIMS-Theoretical Inter-market Margining System) is a binomial option pricing model.
} 
to bring the option within range of the strike price. Little or no margin collateral would be required in many scenarios for such options. The CME version of SPAN includes a minimum charge on written options positions to provide an extra measure of protection. ${ }^{5}$ After the required margin for a set of contracts is computed, the number of written option positions is multiplied by the minimum charge for written options. Required margin is the larger of the requirement computed through SPAN or the written option charge.

The essence of portfolio margining is that the risk exposure generated by a long position of one maturity automatically offsets the risk exposure generated by a short position of another maturity in the same underlying instrument. However, because SPAN uses a single set of price and implied volatilty scan range input settings to estimate potential contract value changes for all options series on an underlying instrument, the approach does not account for the fact that the value of calendar spread positions are subject to losses due to adverse changes in the spread between the prices of contracts with different maturities - a quantity known as the basis. SPAN margin requirements are further modified to require additional margin if portfolios are subject to basis risk. ${ }^{6}$

In addition to calendar spreads in a single underlying instrument, spreads also can be formed using contracts written on different underlying instruments (e.g., the S\&P500 and the S\&P400), and the risk of such combined positions can be less than that on individual contracts alone. SPAN generates risk arrays for individual contracts on each underlying instrument separately. Within the simulation calculations, no credit is given for the potential risk-hedging benefits generated by spread positions across instrument categories. Although not specifically a feature of SPAN, exchanges using a system such as SPAN may provide credits to clearing members to reduce par-

\footnotetext{
${ }^{5}$ Purchased options do not pose the same risk as the maximum that can be lost is the purchase price.

${ }^{6}$ Kupiec (1994) provides more detail.
} 
tially the margin on risk-reducing combinations of contacts on related instruments. The allowed margin offset depends on the correlation between the underlying instruments in the different product groups. As such, SPAN is not a true global portfolio margining system because it does not directly account for cross-product correlations. Rather, SPAN is a true portfolio margining system only for combinations of contracts on a single underlying instrument.

\section{Reg T: Margin Requirements on Stock Options}

A strategy-based margining system, such as that embodied in Reg T, specifies precise positions that may be combined with each other for margining purposes. Reg $\mathrm{T}$ margin regulations specify types of positions that can serve as hedges or offsets for each other and thereby reduce margin requirements. Positions that function as hedges from an economic perspective do not receive credit in margin calculations unless they are part of the enumerated list of acceptable offsets under Reg T.

Writers of options on individual stocks must post margin equal to the market value of the option plus twenty percent of the value of the underlying security. This amount can be reduced, however, by the amount the option is out-of-the money, subject to a minimum margin of ten percent of the underlying plus the option's current market value. A similar margin system is used for a written option on a stock index, but the percentage of the underlying that must be posted varies depending upon whether the index is broadly or narrowly based: Fifteen percent of the underlying must be posted for options on broad indexes, and twenty percent must be posted for options on narrow indexes. Unless they are explicitly included in a recognized Reg $\mathrm{T}$ strategy, purchased options positions do not have collateral value; that is, they cannot be posted to satisfy a margin requirement.

The full list of strategies recognized by Reg $\mathrm{T}$ for margin relief is too lengthy

to enumerate here. A few selected strategies are reviewed, however, so that they can ultimately be compared with the margins that would be required by a portfolio 
approach for the same positions. These positions fall broadly into categories of spread positions and straddles. In many instances, Reg $\mathrm{T}$ will not specify a precise margin requirement for a portfolio. For example, Reg $\mathrm{T}$ does not specify a precise margin for a butterfly or box spread. For these positions margin must be determined by "adding up" the constituent legs in pairs of positions that are recognized strategies entitled to margin relief under Reg $\mathrm{T}$ guidelines. For a complex portfolio of securities and options, there are potentially many ways to assign positions to Reg $\mathrm{T}$ strategies in order to calculate margin requirements. Rudd and Schroeder (1982) show that the efficient (minimum margin) assignment of positions can be formulated as a linear programming problem and solved using the so-called transportation algorithm.

Spreads. Spreads combine written and purchased positions in options of the same type: one or more written calls is combined with one or more purchased calls, and similarly for puts. Reg $\mathrm{T}$ specifies the conditions under which one call option can be offset against another. If an account contains a long call and a short call on the same number of shares of the same underlying security, no margin need be posted on the short position if: (a) the long call does not expire before the short call; and (b) the difference between the exercise price of the long call and the short call, if any, is deposited in the account. Condition (b) requires that the maximum residual cash outflow on the position be on deposit. This outflow is greater than the maximum possible loss on the position, however, because it is offset by any cash inflow from the premiums that the original creation of the position generated. Similar margin cover is allowed for put spreads in Reg T. ${ }^{7}$

In the event the margin for either a call spread or a put spread is greater than that for the naked written position, the margin for the uncovered position can instead be posted. More complex positions such as butterfly spreads using calls, butterfly spreads

\footnotetext{
${ }^{7} \mathrm{~A}$ long put position will serve in lieu of margin for a short put if it is for the same number of shares on the same underlying security and (a) it does not expire before the short put; (b) the amount, if any, by which the exercise price of the short put exceeds the exercise price of the long put is deposited in the margin account.
} 
using puts, and box spreads can be analyzed as groups of written (credit) spreads and purchased (debit) spreads.

Combination Positions (or Straddles). Combination positions, sometimes referred to as straddles, are portfolios that include both puts and calls on the same underlying stock. ${ }^{8}$ Like spreads, combinations also can be either written or purchased. For example, a purchased combination contains both a long put and a long call position. Similarly, in a written combination, both positions are sold or short. Comparable to the margin treatment for a long put position alone or a long call position alone, no loan value is given to a purchased combination: The full price of both the put and the call must be paid.

The required margin on a written combination is determined by evaluating the required margin on the short put and short call positions separately and posting the larger amount. Required margin on the other side of the combination is then based upon its unrealized losses, that is, any in-the-money amount must be posted. Margin is not necessary on both sides of the position because, as prices move, only one of the legs typically will be in the money, and this leg would be margined fully.

\section{A Comparison of SPAN and Reg T Options: Coverage and Efficiency}

In order to compare the efficiency of alternative schemes currently used to margin option instruments, Reg T and SPAN margining rules are applied to various positions constructed using options on stock index futures. The data include price information on the S\&P500 index and S\&P500 stock index futures-options traded on the CME. These data are used to generate the corresponding SPAN and Reg T margin requirements for option portfolios and to assess the coverage these alternative

\footnotetext{
${ }^{8}$ Strictly speaking, a straddle is a special case of a combination position with identical striking prices and expirations. Margin requirements as written are sufficiently general to apply to combination positions although the regulations refer to such positions as "straddles."
} 
margining schemes would have provided over the sample period 12/16/88-12/10/92. ${ }^{9}$ Estimates of SPAN margins are generated using a simulation program that mimics the SPAN margining process. Although Reg $\mathrm{T}$ margin requirements do not apply to stock index-futures positions, the experiment produces a direct comparison of the relative efficiency of these alternative margining systems. ${ }^{10}$

In the analysis that follows, the collateral required by Reg $\mathrm{T}$ on various option portfolios is compared with the margin requirement generated by a simulated SPAN margining system. The margin requirements and coverage rates on naked option positions are analyzed, followed by a comparison of the margin requirements and coverage rates on specific strategies for which Reg $\mathrm{T}$ grants margin relief. The inputs in the SPAN margin estimation process are the historical SPAN inputs used by the CME (table 1). Changes in portfolio values from close to close are calculated and compared to the margin requirements that were in effect based on the previous day's closing prices. If a close-to-close portfolio loss exceeds the position's calculated margin requirement, that observation is recorded as a margin violation.

For each particular strategy analyzed, portfolios are constructed for separate categories defined by the amount by which the constituent options are in or out of the money. For example, for naked written put and call options, each traded option is categorized into 1 of 21 alternative categories defined by the option's moneyness. For more complicated portfolios, the data are also grouped according to selected pairings of the moneyness categories. A call option's moneyness is defined to be the underlying futures price less the option's strike price. For a put option, the moneyness value is the option's strike price less the underlying futures price. Such a categorization is use-

\footnotetext{
${ }^{9}$ The beginning of the sample period corresponds to the date on which SPAN margining was introduced by the CME. There is no particular significance associated with the end of the sample.

${ }^{10}$ Prior to the introduction of SPAN margining on the CME, margins were set using a strategy based system. Following the initial introduction of SPAN, CME clearing members had the choice of being margined under SPAN or the pre-existing CME strategy based system. Such a choice continued until 1990 when the strategy alternative was eliminated. Kupiec (1994) includes an abbreviated comparison of the efficiency of SPAN relative to the CME strategy based system.
} 
ful for comparing the relative magnitudes of the alternative collateral requirements. Under Reg T margin rules, the moneyness values for a portfolio's constituent options are key determinants of the amount of collateral required. Similarly, the amount of collateral required under SPAN will be directly related to the moneyness value of the option. ${ }^{11}$

S\&P500 contracts are quoted as if a contract were a single option (or future) on the index. The actual contract values traded on the CME are $\$ 500 \times$ the quoted index. Values reported in this study are 1/500 of the average dollar amounts of required collateral. That is, they are quoted as the margin that would actually be required per index point.

A summary of the statistical findings is followed by a more detailed discussion of the results for specific alternative strategies examined. Detailed margin comparison estimates for additional strategies that are not reported in the text are available upon request. Readers less interested in the specific details of the margin efficiency comparison can restrict their attention to the summary of the findings and continue with the next section.

Summary of Empirical Findings. On naked written option positions, the simulation-based margin requirements of SPAN provide virtually the same level of day-to-day loss coverage as was provided by the much larger collateral requirements set by Reg T. The estimation results suggest that SPAN margins are substantially more efficient for margining naked options positions. On positions for which Reg T specifically grants margin reductions for a recognized hedge strategy, the portfolio margin set by SPAN generally provides coverage similar to that provided by Reg $\mathrm{T}$ margin rules but with far smaller collateral requirements. In addition, SPAN determines an excess collateral value for a margined portfolio. Any excess collateral value

\footnotetext{
${ }^{11}$ An option's delta value is positively related to its moneyness value. As a consequence, option's with greater moneyness values will generate larger potential loss estimates for a given price scan range setting in the SPAN simulations. Such options will have higher margin requirements.
} 
recognized by SPAN can be used to satisfy a clearing member's margin requirements on other positions at the clearinghouse. ${ }^{12}$ Thus, even on strategies for which Reg $\mathrm{T}$ grants margin relief, the portfolio approach embodied in SPAN is a far more efficient system for collateralizing counterparty risk.

Margins on Naked Written Options. Put and call positions are analyzed separately as the coverage levels may be different owing to the asymmetry in the distribution of price-changes for the S\&P500 index (French, Schwert and Stambaugh, 1987). For example, margin requirements on written put options are more likely to be violated in falling markets whereas margins on written call options will be tested in rising markets. If market volatility is greater in down markets, put option margin requirements may be violated more frequently because neither of these margin approaches accounts for this feature of the return generating process.

The data comparing margin requirements and coverage for a written put or a written call option appear in tables 2 and 3. The data show that Reg $\mathrm{T}$ margins provided 100 percent coverage for all option contracts over all days in this four years period. The SPAN margining system performed only slightly worse, covering 99.87 percent of all put option and 99.95 percent of all call option positions in the historical sample.

All call option violations of the SPAN margin requirements owe to the price move experienced between market close on 10/13/89 and 10/16/89. Over this period, the S\&P500 futures contract rose 15 index points - an amount, which exceeded the SPAN futures price scan range setting of $\$ 5000$ or 10 index points. The violations of the SPAN margin requirements for written puts owe to two market price declines that exceed their respective SPAN price scan range setting: between market close on 3/16/89 and 3/17/89, the S\&P500 index fell 8.5 index points, and between market close on

\footnotetext{
${ }^{12}$ SPAN margins each broad product category separately. For example, domestic equity contract positions are margined separately from fixed income contracts. Any excess collateral value assigned to one margining group can be used to satisfy the margin requirement on other groups.
} 
10/12/89 and 10/13/89, the S\&P500 index declined by about 30 index points. ${ }^{13}$

Although the data show that both systems provided a high degree of collateral protection against one-day price moves, the SPAN margining system provided the protection with substantially smaller average collateral requirements. Reg $\mathrm{T}$ requires a minimum margin of at least ten percent of the value of the underlying (or $\$ 50.00$ per index point), and there were no days during this period when prices on the S\&P500 index moved more than this amount. In contrast, the minimum short option margin in SPAN is $\$ 200$ per contract over this historical period, or $\$ 0.40$ per index point.

The magnitudes of the average margin collateral estimates are comparable for puts and calls. Tables 2 and 3 provide evidence that the minimum written option margin of $\$ 0.40$ per contract has, on average, not been binding on naked written options, even for deep-out-of-the-money options. The average SPAN margin requirements have ranged from $\$ 2.16(\times 500)$ for deep out-of-the-money naked put options to $\$ 15.42$ $(\times 500)$ for deep in-the-money puts or calls. In contrast, Reg T margin requirements averaged from $\$ 34.29(\times 500)$ for deep-out-of-the-money call options to $\$ 106.81(\times 500)$ for the deepest in-the-money put option category. Thus, for deep out-of-the money written options, Reg T collateral requirements are roughly 15 times as large as SPAN collateral requirements, and yet the extra collateral provides less than $1 / 2$ percent additional position coverage over this sample period. For at-the-money options, Reg $\mathrm{T}$ margins require more than 5 times the collateral without providing a significant improvement in margin coverage. For deep in-the-money options, Reg $\mathrm{T}$ requires almost 7 times more collateral without providing any more protection than do SPAN margins.

An alternative way to assess the adequacy and efficiency of margin systems is to examine the days on which coverage is most necessary - those days on which the portfolio lost value. From the perspective of the lender or clearinghouse guaranteeing

\footnotetext{
${ }^{13}$ The scan range was set to cover a price change of 8 index points during these periods.
} 
positions, the concern is whether there is sufficient collateral on days when positions experience losses. The respective columns labeled "average excess margin on loss days" record the average amount by which the margin requirement exceeds the loss in position value. The individual excess collateral values are averaged across all loss days for a given group of contracts with similar moneyness. Both margin systems on average require excess collateral on days when the positions loose value. For Reg T, the excess collateral amounts are very large.

Written Combination Position Margins. In a written combination, both a put and a call are written with the same expiration on the same underlying instrument. The comparative margin performance results for written combination positions are reported in table 4 . The results of the analysis are reported by categories defined by the moneyness of the written puts and calls. Although there are many potential moneyness pairing that could be analyzed, the results for the combination groupings reported in table 4 are representative.

Under Reg T, combination positions may be margined together or separately, if separate treatment results in a lower margin. The third and fourth columns (table 4) present the average required margin under independent and combination margining rules, respectively. The difference in these average margin requirements represents the average amount of margin relief accorded the combination position under the recognized straddle strategy. The amount of margin relief becomes much larger as the options move closer to the money. Although Reg T provides substantial margin relief for some combination positions, Reg $\mathrm{T}$ margins are still significantly larger than the corresponding SPAN margin requirement. A comparison of the Reg $\mathrm{T}$ and SPAN margin requirements (columns 4 and 6) will show that the Reg $T$ collateral requirements are on average between 9 and 20.5 times greater that the corresponding SPAN combination margin. Despite the substantial collateral requirement differential, Reg T margin provides only slightly greater coverage; both margining systems provide virtually complete coverage of the losses experienced during this sample period. 
Butterfly Spread Margins. In a (purchased) butterfly spread, two options close to or at the money are written while an option in-the-money is purchased, and another option out-of-the-money is purchased. For many butterfly spreads, the proceeds from the two written options will only partially offset the premia required to purchase the long option positions. As the option premium must be paid at the time the position is established, the long option positions pose no default risk to the clearinghouse.

In the SPAN margining approach, long option positions have collateral value that can be used to satisfy the margin requirements on short positions. If the value of the long option positions are sufficiently large relative to the risk exposure created by the written options in the portfolio, the portfolio's net market value will exceed its SPAN margin requirement. In this instance, the portfolio's excess collateral value is available to collateralize other contracts. The SPAN margin requirement thus is analogous to a so-called "haircut." A haircut is a deduction from the market value of an asset to cover potential changes in its market value; the net value of the asset, the market value less the haircut, is the value of the asset for capital or collateral purposes. SPAN essentially determines the haircut that applies to the market value of an option portfolio, and the portfolio value net of this haircut can be used to support additional positions at the exchange.

By reducing a butterfly spread's margin requirement from the collateral that would be required on the naked written options in isolation, Reg $\mathrm{T}$ also assigns collateral value to the long option positions in a butterfly spread. However, unlike SPAN, there is no possibility of generating excess collateral value on a portfolio of options; in effect, Reg T implicitly sets the haircut at 100 percent.

Table 5 reports comparative margin data for call butterfly spread positions. The results for put butterfly spread positions (available upon request) are similar. Ten different butterfly spreads are analyzed. The 10 categories are grouped according to the difference between the strike prices on the long option legs of the spread. The average Reg $\mathrm{T}$ margin requirement reported is the average additional collateral over 
and above any collateral value implicitly assigned to the long option legs of the spread. The average SPAN margin requirement reported is the average total collateral needed to sustain the respective butterfly spread portfolio. If the net market value of the butterfly spread exceeds its SPAN margin requirement, the portfolio has positive excess collateral value. If the net market value of the butterfly spread is less than the SPAN margin, the portfolio has negative excess collateral value and additional margin collateral must be posted to maintain the position. The final column in tables 6 provides estimates of the sample averages of these portfolios' excess collateral values under SPAN. The results show that the SPAN margin covered all the market risk in these portfolios' values (day-to-day fluctuations in collateral value) and, in many cases, released substantial amounts of collateral that could have been used to support other positions at the exchange.

The estimates reported in table 5 show that Reg $\mathrm{T}$ margins covered 100 percent of all butterfly spread losses experienced during the sample period. The performance of SPAN margins was virtually identical to that reported by Reg $\mathrm{T}$ as the poorest performing spread category posted a coverage rate of 99.71 percent under SPAN. Similar to the results reported for naked written options, SPAN achieved coverage virtually identical to Reg T with substantially smaller margin requirements. Depending on the butterfly spread group examined, average SPAN margin requirements range from 12 to 37 percent of the Reg $\mathrm{T}$ margin over this sample period. Not only were SPAN margins substantially lower, SPAN credits many of these portfolios with significant excess collateral value - value that can be used to collateralize other positions at the exchange.

An example may clarify the differences between these alternative margining systems. Consider the first row of table 5, the results for a butterfly spread with a deep in-the-money and a deep out-of-the-money long call option. To establish this position, the holder must pay the difference between the premium on the long options less the premium received for writing the short option legs. In addition, the holder must on 
average post $\$ 60.90(\times 500)$ in additional collateral to satisfy Reg T margins. Under SPAN the margin requirement on this portfolio is on average, $\$ 7.36(\times 500)$. For this group of spreads, the average net value of the portfolio exceeds the SPAN margin requirement by $\$ 19.41(\times 500)$. In other words, SPAN credits this portfolio with $\$ 19.41$ $(\times 500)$ in excess collateral value that can be used to satisfy margin requirements on other positions. In contrast, Reg $\mathrm{T}$ does not assign any excess collateral value to this position.

\section{Why Do Margining Systems Differ?}

The margin comparison results document dramatic differences in the margin requirements imposed by two different types of margining systems. Such differences raise questions as to why two such radically different margining systems persist for products that have fundamentally the same characteristics. To some extent, the differences in margining systems may owe to historical and institutional differences between the securities and futures industries. Notwithstanding these effects, the co-existence of these alternative margining systems also likely owes to differences in the structure of regulatory oversight across these markets.

The observed differences in the efficiencies of these alternative margining systems are broadly consistent with the predictions of the regulatory competition model of Kane (1984). Kane treats competition among regulators as a variant of competition among firms. In his model, regulatory competition serves to minimize the "tax" imposed by regulation. Industries with systems of self-regulation are encompassed within this model. SROs engage in competition both with each other and with regulatory bodies charged with overseeing their operations. Kane's model posits that, in a comparison of industry self-regulation versus direct governmental regulation, SRO

decision making will be more proactive with a greater potential for "regulatory tax" reduction relative to direct governmental regulation which will tend to be reactive. 
The FRB was given margin authority for securities as a result of the Securities and Exchange Act of 1934. The scope of the FRB's margin authority in securities markets is extremely broad. All securities other than exempted securities (U.S. government, agency securities, and local government securities) are covered by Reg T, and FRB regulation encompasses many aspects of the lending process other than the level of margins. ${ }^{14}$ Among the primary motivations for initially granting the FRB margin authority was the congressional belief that margin requirements could be used to stem speculative excesses in securities markets. Although in modern times the FRB has discounted the possibility that margin requirements are a useful tool for controlling market volatility, some still maintain that margin requirements can be used to control excessive speculation. ${ }^{15}$

Originally, options were only traded over-the-counter and margin had been set by Reg $\mathrm{T}$ to be the amount customarily required by creditors. When options on securities were first listed on exchanges, the FRB devised a scheme for margining them that was modeled after the existing Reg $\mathrm{T}$ framework for margining exchange-traded securities. The margin required for short option positions was thirty percent of the value of the underlying stock on which the option was written, similar to the scheme for margining short positions in stocks. Loan value for long option positions was denied, however, in contrast to the treatment for long stock positions. ${ }^{16}$ About ten years later, this regulatory system for option margining was changed to the current system that is based upon the mark-to-market value of the option plus a certain percentage of the

\footnotetext{
${ }^{14}$ Current coverage of securities-margin regulation addresses: all financial relations between broker and customer, the types of collateral on which brokers can extend credit, the amount of credit obtainable on certain combinations of positions (hedges, for example), margin for short sales, time periods for customer payment, credit available to market makers and specialists, the borrowing and lending of securities, and arranging for the extension of credit by broker-dealers. This is not an exhaustive list, but it indicates the broad scope of the FRB's securities regulation.

${ }^{15}$ For the FRB position, see Chairman Greenspan's testimony before the House Subcommittee on Telecommunications and Finance, November 30, 1995. For some alternative views, see Hardouvelis (1990), or SEC Chairman's Ruder's view expressed in the "Interim Report of the Working Group on Financial Markets", May 1988. page 6.

${ }^{16} \mathrm{~A}$ major reason that loan value was denied is that options are a wasting asset.
} 
value of the underlying. The revised system retained the strategy-based aspects of the earlier system and continued to deny long options loan value.

While the strategy-based Reg T system continues to be applicable for customer positions, an alternative margining system has evolved at the OCC, the clearing entity for all exchange-traded securities options. Under the rules of Reg T, securities-option specialists and registered market makers are granted relief from Reg $\mathrm{T}$ customer option margin requirements on transactions that occur through a "market function account". As a result, the securities posted as collateral with the OCC are exempt from Reg T, enabling the OCC to design its own margining system for the clearing process. The securities-option market maker accounts and the proprietary accounts of OCC clearing members are collateralized according to OCC rules as approved by the SEC. Initially, the OCC rules margined market maker and clearing member options portfolios using an OCC specific strategy-based pairing algorithm [see Sofianos (1988)]. As technology improved, the OCC adopted rule changes (approved by the SEC) requiring that portfolio simulation-based margining procedures be used to margin the positions of clearing members and market makers. The margining system used by the OCC (TIMS) is roughly comparable to SPAN. ${ }^{17}$

Despite new technology and the changes incorporated in the clearing process for securities options, few changes have been made in the Reg $\mathrm{T}$ rules that determine margin requirements for customer positions of these instruments. Although the FRB has requested comment on changes in Reg $\mathrm{T}$ that would give a greater role to SROs in determining the margin requirements for options positions, such changes have not yet been finalized. ${ }^{18}$

\footnotetext{
${ }^{17}$ Conversations with the staff at the CME and OCC clearinghouses indicate that, given comparable margin-setting control parameters, clearinghouse research conducted in conjunction with the design of cross-margining agreements showed that TIMS and SPAN produce roughly equivalent margin requirements.

${ }^{18}$ See for example the November 3, 1995 testimony of Chairman Greenspan, opt. cit. in which he re-iterated the Board's position that self-regulatory organizations should be given greater responsibility for margin regulation.
} 
In contrast to the securities markets, the tradition in futures markets has been much more portfolio oriented. A default, regardless of the contract that precipitated it, will lead to the liquidation of the clearing member's entire portfolio. As margins are set to protect the clearinghouse against the overall risk generated by the daily fluctuations in the values of all positions held by a clearing member, it is more natural that a portfolio margining scheme would develop. Originally, the futures exchanges used a delta-based system to convert options positions into futures equivalents in order to margin them (Figlewski (1984)). Delta-based techniques did not produce accurate reflections of the risk of option positions, and this weakness was widely recognized within the industry. Simulation-based portfolio approaches were developed to address the weaknesses of the delta-based approaches and are currently used for both customer and clearing member margins at U.S. futures clearinghouses. Although competing portfolio margining approaches were developed by other futures exchanges, to date, SPAN has become the dominant approach used by futures clearinghouses.

The historical evolution of margining systems provides support for Kane's observation that $\mathrm{SRO}$ regulation is more proactive while governmental regulation tends to be more reactive. In the context of Kane's model, the competition among futures clearinghouse SROs would create incentives to minimize the costs of providing the contract performance guarantee. If margin is costly, cost minimization requires the adoption of a margin system that efficiently collateralizes a derivative portfolio's oneday risk exposure. Portfolio margining systems that incorporate an explicit option pricing model first developed at clearing organizations for use with clearing members. Although the rules of these SROs are approved by governmental regulators, the regulators generally have given much greater latitude to the SROs in their development of margining procedures for clearing members than for customers. In response to the regulatory environment, SROs initiated the creation of portfolio margining systems which were then approved by the relevant regulatory body. Consistent with the prediction's of the Kane model, margin regulations affecting clearing members, while not 
identical, have evolved into similar procedures across clearinghouses and product markets. As the results of this paper demonstrate, such portfolio margining techniques are substantially more efficient than the strategy-based alternative approach.

The proactive regulatory behavior of SRO is in contrast to the Reg T experience in which changes have been enacted only as a response to petitions by market participants or SROs. The regulatory treatment of securities-option customers does not suggest that competition has been very effective at lowering the tax implicitly imposed by regulation. As the results indicate, Reg $\mathrm{T}$ leaves little question that its margin requirements are adequate to the task of providing prudential coverage. However adequate, the results do suggest that the benefits of regulatory competition have largely eluded securities-options customers as a portfolio approach to margining could provide virtually the same level of prudential coverage with a significantly lower "regulatory tax". Although the Reg T standards can be modified to accommodate technology advances into the customer margining rules, the process appears to have been at least partially shielded from the efficiency pressures that were generated by the competition among SROs for clearing member margin reform.

In defending the strategy-based rules of Reg $T$, it has sometimes been asserted that a portfolio approach to margining would be too confusing for the average customer and that there is not enough consensus on the design of such a system among market participants and regulators. These arguments, however, ignore the complexity of the current system (it is doubtful if customers with a portfolio of options have any idea how these positions are being combined by their brokers to determine their margin requirements) and the strong similarities in the portfolio margining systems that have been developed to set clearing member margins in the futures and options markets.

Another potential impediment to wholesale Reg $\mathrm{T}$ customer margin reform is the lingering belief that margins might be a useful tool for controlling stock market volatility. Uniform adoption of an existing scheme for portfolio margining would require a significant reduction in the current 50 percent initial margin requirement 
that applies to stock purchases. For those who believe that margin requirements can be a useful device to control speculative excess, such a reduction may not be welcome.

\section{Conclusions}

The portfolio margining system embodied in SPAN provides substantially the same market risk protection as the strategy-based system of Reg $\mathrm{T}$ but with collateral levels that are mere fractions of those required by Reg T. The efficiency gains of SPAN arise from two sources. First, SPAN uses option pricing simulations to accurately measure potential one-day risk exposures on instruments. In contrast, Reg T implicitly estimates the potential risk exposure as a percentage of the value of the underlying instrument, an amount which is only indirectly related to the risk of a contract. These implicit risk exposure estimates grossly overstate the one-day market risk in individual options positions. Secondly, SPAN uses the option pricing simulations to accurately estimate the appropriate collateral requirement offsets within a portfolio of futures options. In the margining process, SPAN implicitly assigns collateral value to any option in a portfolio. In contrast, Reg $\mathrm{T}$ only accords collateral value to options in specifically recognized strategies. Even within these strategies, the Reg T estimate of the recognized option's collateral value is inaccurate, erring on the side of prudential caution.

The regulatory competition model of Kane (1984) provides a framework that may in part explain the structure of these existing margin regulations. The results of this study are consistent with Kane's hypothesis that active regulatory competition among SROs will reduce the implicit "tax" associated with regulatory oversight. Specificly, margin requirements for clearing member positions in both securities options markets and futures markets share the efficiency gains generated by adopting portfolio margining procedures. In contrast, customer margin requirements for options on securities, an area lacking strong competition in the regulatory structure, appear to suffer un- 
necessarily large "regulatory tax" burdens when compared against alternatives that provide a comparable level of prudential coverage.

Although the empirical estimates presented are specific to Reg T and the SPAN system, the qualitative results will hold in a comparison of any alternative portfolio and strategy-based approaches. When margining option portfolios against shorthorizon market risk exposure, strategy-based approaches are inherently less efficient as they sacrifice the accuracy available from using pricing model simulations for the alleged simplicity of formula-based approaches. The results of this study complement those of Dimson and Marsh (1995) who also document the superiority of a portfolio approach for setting capital requirements for U.K. securities dealer's portfolios of common stocks. Choices between portfolio simulation-based systems and strategy-based systems arise in other contexts besides margins, however. Similar kinds of choices are being decided with regard to the market-risk capital requirement for the trading portfolios of banks and are relevant for the design of bilateral collateralization agreements for over-the-counter derivatives contracts. These results argue for consideration of a portfolio approach. 


\section{References}

[1] Anderson, R. (1981) "Comments on 'Margins and Futures Contracts'," The Journal of Futures Markets, 1:2, pp. 259-264.

[2] Black, F. (1976) "The Pricing of Commodity Contracts," Journal of Financial Economics, 3:1/2, pp. 167-79.

[3] Dimson, E. and P. Marsh (1995) "Capital Requirements for Securities Firms," Journal of Finance, 50:3, pp. 1219-1233.

[4] Brenner, T. W. (1981) "Margin Authority: No Reason for a Change," The Journal of Futures Markets, 1, Supplement, pp. 487-490.

[5] Fenn, G., and P. Kupiec. (1993) "Prudential Margin Policy in a Futures-Style Settlement System," The Journal of Futures Markets, 13:4, pp. 389-408.

[6] Fishe, R. and L. Goldberg (1986) "The Effects of Margins on Trading in the Futures Markets," The Journal of Futures Markets, 6:2, pp. 261-271.

[7] Figlewski, S. (1984) "Margins and Market Integrity: Margin Setting for Stock Index Futures and Options," The Journal of Futures Markets, 4:3, pp. 385-416.

[8] French, K., G. Schwert and R. Stambaugh (1987) "Expected Stock Returns and Volatility," Journal of Financial Economics, 19:1, pp. 3-30.

[9] Gay, G., W. Hunter, and R. Kolb (1986) "A Comparative Analysis of Futures Contract Margins", The Journal of Futures Markets, 6:2, pp. 307-324.

[10] Hardouvelis, G. (1990) "Margin Requirements, Volatility, and the Transitory Component of Stock Prices," American Economic Review, 80:736-762.

[11] Hartzmark, M. (1986) "The Effects of Changing Margin Levels on Futures Market Activity, the Composition of Traders in the Market, and Price Performance," Journal of Business, 59:2, pp. S147-S180.

[12] Kane, E. (1984) "Regulatory Structure in Futures Markets: Jurisdictional Competition between the SEC, the CFTC, and Other Agencies," The Journal of Futures Markets, 4:3, pp. 367-384.

[13] Kupiec P. (1994) "The Performance of S\&P500 Futures Product Margins under the SPAN Margining System," The Journal of Futures Markets, 14:7, pp. 789-812.

[14] Kupiec P., and J. O’Brien (1996) "Recent Developments in Bank Capital Regulation of Market Risks." In Barry Schachter, editor, Advances in Finance, Investment and Banking: Derivatives and Banking Regulation. Amsterdam: NorthHolland, forthcoming. 
[15] "An Internal Model-Based Approach to Market Risk Capital Requirements", (April 1995). Bank For International Settlements: Basle Committee on Banking Supervision.

[16] Petzel, T., (1995) "Managing Collateral on Exchanges and Off: A New Perspective," Journal of Derivatives, Spring, pp. 64-72.

[17] Rudd, A. and M. Schroeder (1982) "The Calculation of Minimum Margin," Management Science, 28:12, pp. 1368-1379.

[18] Sofianos, G. (1988) "Margin Requirements on Equity Instruments," Federal reserve Bank of New York Quarterly Review, Summer, pp. 47-60.

[19] Telser, L. (1981) "Margins and Futures Contracts," The Journal of Futures Markets, 1:2, pp. 225-253.

[20] "Interim Report of The Working Group on Financial Markets," (May 1988) Washington, D.C.

[21] Tomek, W. (1985) "Margins of Futures Contracts: Their Economic Roles and Regulation." In Anne E. Peck, editor, Futures Markets: Regulatory Issues. American Enterprise Institute, pp. 143-209. 
Table 1: Historical SPAN Input Settings for Clearing Members, Market Makers, and Hedge Accounts on SESP50 Products at the Chicago Mercantile Exchange

\begin{tabular}{|c|c|c|c|c|}
\hline Date & $\begin{array}{c}\text { Futures Price } \\
\text { Scan Range }\end{array}$ & $\begin{array}{c}\text { Implied } \\
\text { Volatility } \\
\text { Scan Range }\end{array}$ & $\begin{array}{c}\text { Short Option } \\
\text { Minimum }\end{array}$ & $\begin{array}{c}\text { Calendar } \\
\text { Spread Charge }\end{array}$ \\
\hline $12 / 16 / 88$ & 4,000 & 3.50 & 100 & 200 \\
$1 / 12 / 89$ & 4,000 & 2.25 & 100 & 200 \\
$3 / 02 / 89$ & 4,000 & 2.30 & 100 & 200 \\
$10 / 13 / 89$ & 5,000 & 2.30 & 125 & 200 \\
$10 / 16 / 89$ & 6,000 & 2.30 & 150 & 200 \\
$2 / 13 / 90$ & 6,000 & 3.50 & 150 & 200 \\
$3 / 20 / 90$ & 6,000 & 3.00 & 150 & 200 \\
$4 / 09 / 90$ & 7,500 & 3.00 & 188 & 200 \\
$7 / 16 / 90$ & 8,000 & 3.00 & 200 & 200 \\
$9 / 11 / 90$ & 8,000 & 3.50 & 200 & 200 \\
$1 / 14 / 91$ & 10,000 & 3.50 & 250 & 200 \\
$3 / 07 / 91$ & 10,000 & 3.00 & 250 & 200 \\
$4 / 10 / 91$ & 9,000 & 3.00 & 225 & 200 \\
$5 / 07 / 91$ & 9,000 & 2.50 & 225 & 200 \\
$3 / 24 / 92$ & 9,000 & 1.50 & 225 & 200 \\
$6 / 22 / 92$ & 8,000 & 1.50 & 200 & 200 \\
\hline
\end{tabular}

NOTES: The calendar dates are the effective dates on which any of the SPAN input parameters for clearing members, market makers, or hedge accounts changed. These values are appear in the CME's, "S\&P500Performance Bond History." 
Table 2: Estimates of the Historical Margin Requirements, Percent Coverage Rates, and Excess Margin Collateral on Written Futures Put-Option Positions Margined with SPAN using the CME's Input Settings and Reg T Margin Requirements

\begin{tabular}{|c|c|c|c|c|c|c|}
\hline $\begin{array}{l}\text { Moneyness } \\
\text { Value for } \\
\text { the Option }\end{array}$ & $\begin{array}{c}\text { SPAN } \\
\text { Margin } \\
\text { Coverage }\end{array}$ & $\begin{array}{l}\text { Average } \\
\text { SPAN } \\
\text { Margin }\end{array}$ & $\begin{array}{c}\text { Reg T } \\
\text { Margin } \\
\text { Coverage }\end{array}$ & $\begin{array}{l}\text { Average } \\
\text { Reg T } \\
\text { Margin }\end{array}$ & $\begin{array}{l}\text { Ave Excess } \\
\text { SPAN Margin } \\
\text { on Loss Days }\end{array}$ & $\begin{array}{l}\text { Ave Excess } \\
\text { Reg T Margin } \\
\text { on Loss Days }\end{array}$ \\
\hline$<-52.5$ & 99.79 & 2.16 & 100.00 & 35.47 & 1.50 & 36.26 \\
\hline-52.5 to -47.5 & 99.82 & 2.29 & 100.00 & 34.70 & 2.48 & 35.98 \\
\hline-47.5 to -42.5 & 99.69 & 2.75 & 100.00 & 34.71 & 2.40 & 35.74 \\
\hline-42.5 to -37.5 & 99.81 & 3.14 & 100.00 & 34.67 & 3.26 & 35.93 \\
\hline-37.5 to -32.5 & 99.82 & 3.70 & 100.00 & 34.81 & 3.56 & 35.67 \\
\hline-32.5 to -27.5 & 99.85 & 4.31 & 100.00 & 35.26 & 4.06 & 36.28 \\
\hline-27.5 to -22.5 & 99.88 & 5.19 & 100.00 & 35.81 & 4.61 & 36.43 \\
\hline-22.5 to -17.5 & 99.90 & 6.09 & 100.00 & 36.64 & 5.29 & 37.14 \\
\hline-17.5 to -12.5 & 99.88 & 7.11 & 100.00 & 39.14 & 5.92 & 39.39 \\
\hline-12.5 to -7.5 & 99.90 & 8.09 & 100.00 & 45.17 & 6.59 & 45.31 \\
\hline-7.5 to -2.5 & 99.88 & 9.22 & 100.00 & 51.33 & 7.42 & 50.72 \\
\hline-2.5 to +2.5 & 99.87 & 10.22 & 100.00 & 57.41 & 8.13 & 56.63 \\
\hline+2.5 to +7.5 & 99.83 & 11.30 & 100.00 & 60.15 & 9.02 & 58.92 \\
\hline+7.5 to +12.5 & 99.90 & 12.11 & 100.00 & 63.01 & 9.55 & 61.55 \\
\hline+12.5 to +17.5 & 99.92 & 12.98 & 100.00 & 66.82 & 10.36 & 65.23 \\
\hline+17.5 to +22.5 & 100.00 & 13.78 & 100.00 & 72.01 & 10.95 & 70.11 \\
\hline+22.5 to +27.5 & 100.00 & 14.47 & 100.00 & 76.78 & 11.25 & 74.76 \\
\hline+27.5 to +32.5 & 100.00 & 14.57 & 100.00 & 81.02 & 11.27 & 79.00 \\
\hline+32.5 to +37.5 & 100.00 & 14.83 & 100.00 & 85.61 & 11.38 & 83.39 \\
\hline+37.5 to +42.5 & 100.00 & 15.02 & 100.00 & 90.07 & 11.49 & 88.04 \\
\hline$>+42.5$ & 100.00 & 15.42 & 100.00 & 106.81 & 11.60 & 105.08 \\
\hline
\end{tabular}

NOTES: For a put option, its moneyness is the option's strike price less the underlying futures price. The sample period is $12 / 16 / 88-12 / 10 / 92$. The overall coverage rates are 99.87 for SPAN and 100 percent for Reg $\mathrm{T}$. The average excess margin on loss days is the average amount by which the respective margin requirement exceeded the loss on the position. The actual average margin or excess margin on an S\&P500 contract is $500 \times$ the amounts reported. 
Table 3: Estimates of the Historical Margin Requirements, Percent Coverage Rates, and Excess Margin Collateral on Written Futures Call-Option Positions Margined with SPAN using the CME's Input Settings and Reg T Margin Requirements

\begin{tabular}{|c|c|c|c|c|c|c|}
\hline $\begin{array}{c}\text { Moneyness } \\
\text { Value for } \\
\text { the Option }\end{array}$ & $\begin{array}{c}\text { SPAN } \\
\text { Margin } \\
\text { Coverage }\end{array}$ & $\begin{array}{c}\text { Average } \\
\text { SPAN } \\
\text { Margin }\end{array}$ & $\begin{array}{c}\text { Reg T } \\
\text { Margin } \\
\text { Coverage }\end{array}$ & $\begin{array}{c}\text { Average } \\
\text { Reg T } \\
\text { Margin }\end{array}$ & $\begin{array}{c}\text { Ave Excess } \\
\text { SPAN Margin } \\
\text { on Loss Days }\end{array}$ & $\begin{array}{c}\text { Ave Excess } \\
\text { Reg T Margin } \\
\text { on Loss Days }\end{array}$ \\
\hline-52.5 to -47.5 & 100.00 & 2.89 & 100.00 & 34.29 & 3.63 & 34.51 \\
-47.5 to -42.5 & 100.00 & 3.47 & 100.00 & 34.51 & 5.13 & 35.03 \\
-42.5 to -37.5 & 100.00 & 4.29 & 100.00 & 35.24 & 6.85 & 35.17 \\
-37.5 to -32.5 & 100.00 & 4.87 & 100.00 & 35.81 & 6.19 & 35.25 \\
-32.5 to -27.5 & 99.96 & 5.49 & 100.00 & 35.87 & 6.60 & 36.14 \\
-27.5 to -22.5 & 99.91 & 6.16 & 100.00 & 35.08 & 6.80 & 35.80 \\
-22.5 to -17.5 & 99.92 & 6.73 & 100.00 & 35.42 & 6.92 & 35.21 \\
-17.5 to -12.5 & 99.92 & 7.70 & 100.00 & 37.73 & 7.22 & 35.23 \\
-12.5 to -7.5 & 99.92 & 8.65 & 100.00 & 43.84 & 7.62 & 43.20 \\
-7.5 to -2.5 & 99.95 & 9.73 & 100.00 & 50.67 & 8.06 & 49.80 \\
-2.5 to +2.5 & 99.95 & 10.63 & 100.00 & 57.54 & 8.50 & 56.23 \\
+2.5 to +7.5 & 99.97 & 11.55 & 100.00 & 61.18 & 9.04 & 59.67 \\
+7.5 to +12.5 & 99.97 & 12.29 & 100.00 & 64.77 & 9.60 & 63.07 \\
+12.5 to +17.5 & 99.93 & 12.98 & 100.00 & 68.27 & 10.10 & 66.33 \\
+17.5 to +22.5 & 99.96 & 13.52 & 100.00 & 72.22 & 10.51 & 70.24 \\
+22.5 to +27.5 & 99.90 & 14.02 & 100.00 & 76.57 & 10.89 & 74.15 \\
+27.5 to +32.5 & 99.94 & 14.58 & 100.00 & 81.14 & 11.47 & 79.02 \\
+32.5 to +37.5 & 100.00 & 15.06 & 100.00 & 86.54 & 11.79 & 84.58 \\
+37.5 to +42.5 & 99.92 & 15.29 & 100.00 & 91.72 & 11.98 & 89.76 \\
$>>42.5$ & 99.95 & 15.42 & 100.00 & 101.75 & 12.13 & 99.49 \\
\hline
\end{tabular}

NOTES: For a call option, its moneyness is the futures price less the option's strike price. The sample period is $12 / 16 / 88-12 / 10 / 92$. The overall coverage rate is 99.95 percent for SPAN and 100 percent for Reg T. The average excess margin on loss days is the average amount by which the respective margin requirement exceeded the loss on the position. The actual average margin or excess margin on an S\&P500 contract is $500 \times$ the amounts reported. 
Table 4: Estimates of the Historical Margin Requirements and Coverage Rates on Written Combination Positions (Straddles) Margined with SPAN and Reg T Rules

\begin{tabular}{|c|c|c|c|c|c|c|}
\hline $\begin{array}{c}\text { Moneyness } \\
\text { Value } \\
\text { of Option }\end{array}$ & $\begin{array}{c}\text { Short } \\
\text { Option } \\
\text { Position }\end{array}$ & $\begin{array}{c}\text { Average } \\
\text { Reg T } \\
\text { Margined } \\
\text { Separately }\end{array}$ & $\begin{array}{c}\text { Average } \\
\text { Reg T } \\
\text { Straddle } \\
\text { Margin }\end{array}$ & $\begin{array}{c}\text { Reg T \% } \\
\text { Margin } \\
\text { Coverage }\end{array}$ & $\begin{array}{l}\text { Average } \\
\text { SPAN } \\
\text { Margin }\end{array}$ & $\begin{array}{c}\text { SPAN \% } \\
\text { Margin } \\
\text { Coverage }\end{array}$ \\
\hline $\begin{array}{l}<-52.5 \\
<-52.5\end{array}$ & $\begin{array}{l}\text { short call } \\
\text { short put }\end{array}$ & 77.72 & 76.24 & 100.00 & 3.75 & 100.00 \\
\hline $\begin{array}{l}-52.5 \text { to }-47.5 \\
-52.5 \text { to }-47.5 \\
\end{array}$ & $\begin{array}{l}\text { short call } \\
\text { short put }\end{array}$ & 78.86 & 76.57 & 100.00 & 3.84 & 100.00 \\
\hline $\begin{array}{l}-47.5 \text { to }-42.5 \\
-47.5 \text { to }-42.5\end{array}$ & $\begin{array}{l}\text { short call } \\
\text { short put }\end{array}$ & 79.99 & 78.05 & 100.00 & 3.86 & 100.00 \\
\hline $\begin{array}{l}-42.5 \text { to }-37.5 \\
-42.5 \text { to }-37.5\end{array}$ & $\begin{array}{l}\text { short call } \\
\text { short put }\end{array}$ & 79.56 & 76.53 & 100.00 & 3.91 & 100.00 \\
\hline $\begin{array}{l}-37.5 \text { to }-32.5 \\
-37.5 \text { to }-32.5 \\
\end{array}$ & $\begin{array}{l}\text { short call } \\
\text { short put }\end{array}$ & 80.42 & 74.95 & 100.00 & 4.27 & 99.95 \\
\hline $\begin{array}{l}-32.5 \text { to }-27.5 \\
-32.5 \text { to }-27.5 \\
\end{array}$ & $\begin{array}{l}\text { short call } \\
\text { short put }\end{array}$ & 80.29 & 70.53 & 100.00 & 4.64 & 99.96 \\
\hline $\begin{array}{l}-27.5 \text { to }-22.5 \\
-27.5 \text { to }-22.5\end{array}$ & $\begin{array}{l}\text { short call } \\
\text { short put }\end{array}$ & 81.03 & 65.96 & 100.00 & 5.09 & 99.91 \\
\hline $\begin{array}{l}-22.5 \text { to }-17.5 \\
-22.5 \text { to }-17.5\end{array}$ & $\begin{array}{l}\text { short call } \\
\text { short put }\end{array}$ & 81.83 & 58.05 & 100.00 & 5.40 & 99.89 \\
\hline $\begin{array}{l}-17.5 \text { to }-12.5 \\
-17.5 \text { to }-12.5 \\
\end{array}$ & $\begin{array}{l}\text { short call } \\
\text { short put }\end{array}$ & 89.98 & 55.00 & 100.00 & 5.89 & 99.89 \\
\hline $\begin{array}{l}-12.5 \text { to }-7.5 \\
-12.5 \text { to }-7.5\end{array}$ & $\begin{array}{l}\text { short call } \\
\text { short put }\end{array}$ & 102.43 & 58.25 & 100.00 & 6.27 & 99.87 \\
\hline $\begin{array}{l}-7.5 \text { to }-2.5 \\
-7.5 \text { to }-2.5\end{array}$ & $\begin{array}{l}\text { short call } \\
\text { short put }\end{array}$ & 116.33 & 61.32 & 100.00 & 6.64 & 99.84 \\
\hline
\end{tabular}

NOTES: The sample period is $12 / 16 / 88-12 / 10 / 92$. The actual average margin requirements on the S\&P500 straddle positions would be $500 \times$ the average margin values reported in the table. The column entitled, "Average Reg-T Margined Separately," is the average Reg-T margin that would be required if the two options were margined separately under Reg-T. 
Table 5: Estimates of the Historical Margin Requirements and Coverage Rates on Call Butterfly Spread Portfolios Margined with SPAN and Reg T Rules

\begin{tabular}{|c|c|c|c|c|c|c|}
\hline $\begin{array}{c}\text { Moneyness } \\
\text { Value } \\
\text { of Option }\end{array}$ & $\begin{array}{c}\text { Long } \\
\text { Option } \\
\text { Position }\end{array}$ & $\begin{array}{l}\text { Average } \\
\text { Reg T } \\
\text { Margin }\end{array}$ & $\begin{array}{c}\text { Reg T \% } \\
\text { Margin } \\
\text { Coverage }\end{array}$ & $\begin{array}{l}\text { Average } \\
\text { SPAN } \\
\text { Margin }\end{array}$ & $\begin{array}{c}\text { SPAN \% } \\
\text { Margin } \\
\text { Coverage }\end{array}$ & $\begin{array}{l}\text { Average Excess } \\
\text { SPAN } \\
\text { Collateral Value }\end{array}$ \\
\hline $\begin{array}{l}<-52.5 \\
>+42.5\end{array}$ & $\begin{array}{l}\text { long call } \\
\text { long call }\end{array}$ & 60.90 & 100.00 & 7.36 & 100.00 & 19.41 \\
\hline $\begin{array}{l}-52.5 \text { to }-47.5 \\
+37.5 \text { to }+42.5\end{array}$ & $\begin{array}{l}\text { long call } \\
\text { long call }\end{array}$ & 50.00 & 100.00 & 7.28 & 100.00 & 12.97 \\
\hline $\begin{array}{l}-47.5 \text { to }-42.5 \\
+32.5 \text { to }+37.5\end{array}$ & $\begin{array}{l}\text { long call } \\
\text { long call }\end{array}$ & 45.00 & 100.00 & 7.02 & 100.00 & 10.41 \\
\hline $\begin{array}{l}-42.5 \text { to }-37.5 \\
+27.5 \text { to }+32.5\end{array}$ & $\begin{array}{l}\text { long call } \\
\text { long call }\end{array}$ & 40.00 & 100.00 & 6.95 & 100.00 & 6.46 \\
\hline $\begin{array}{l}-37.5 \text { to }-32.5 \\
+22.5 \text { to }+27.5\end{array}$ & $\begin{array}{l}\text { long call } \\
\text { long call }\end{array}$ & 35.00 & 100.00 & 6.56 & 100.00 & 3.91 \\
\hline $\begin{array}{l}-32.5 \text { to }-27.5 \\
+17.5 \text { to }+22.5\end{array}$ & $\begin{array}{l}\text { long call } \\
\text { long call }\end{array}$ & 30.00 & 100.00 & 6.20 & 100.00 & -0.57 \\
\hline $\begin{array}{l}-27.5 \text { to }-22.5 \\
+12.5 \text { to }+17.5\end{array}$ & $\begin{array}{l}\text { long call } \\
\text { long call }\end{array}$ & 25.00 & 100.00 & 5.57 & 99.95 & -2.59 \\
\hline $\begin{array}{l}-22.5 \text { to }-17.5 \\
+7.5 \text { to }+12.5\end{array}$ & $\begin{array}{l}\text { long call } \\
\text { long call }\end{array}$ & 20.00 & 100.00 & 5.24 & 99.97 & -5.66 \\
\hline $\begin{array}{l}-17.5 \text { to }-12.5 \\
+2.5 \text { to }+7.5\end{array}$ & $\begin{array}{l}\text { long call } \\
\text { long call }\end{array}$ & 15.00 & 100.00 & 4.68 & 99.99 & -7.40 \\
\hline $\begin{array}{l}-12.5 \text { to }-7.5 \\
+2.5 \text { to }+7.5\end{array}$ & $\begin{array}{l}\text { long call } \\
\text { long call }\end{array}$ & 10.00 & 100.00 & 3.66 & 99.71 & -4.97 \\
\hline
\end{tabular}

NOTES: The short side of each butterfly spread is composed of 2 written call options of the same expiration series in the moneyness category [-2.5 to +2.5$]$. The sample period is $12 / 16 / 88-12 / 10 / 92$. The actual average margin requirements (and excess collateral values) on the S\&P500 butterfly spread positions would be $500 \times$ the average margin values reported in the table. 